\title{
[RE]KONSTRUKSI AKUNTABILITAS: SEBUAH TINJAUAN AKUNTANSI DAN SISTEM INFORMASI DARI PERSPEKTIF LOKAL
}

\author{
Ratna Ayu Damayanti \\ damayantiss@yahoo.co.id \\ Syarifuddin \\ syarif1963@yahoo.com \\ Darmawati \\ darmajuanda03@gmail.com \\ Aini Indrijawati \\ ainiindrijawati@yahoo.com \\ Fakultas Ekonomi Universitas Hasanuddin
}

\begin{abstract}
Accounting reforms in the public sector aims to improve the quality of information provided to decision makers and stakeholders. Improving the quality of information needed to drive accountability and performance in public sector organizations. This is important because the accounting information plays a key role in decision-making in the organization. This study aims to determine "how accounting information is interpreted by the community and Gowa local government in the construction of public accountability". This study involves an interpretive methodology that uses the perspective of understanding nominalism from the nominalists who see social reality as something that is none other than the label, name, or concept that is used to construct reality. The nominalists view that there is no real thing. The names are only considered as artificial creations whose utility depends on the appropriateness of describing, giving meaning, and negotiate something or the outside world. The study found that the Gowa local government has not made a voluntary effort to adjust the model management and reporting of accountability to the specific needs of their community. Such adjustments should begin with a clear definition of the objectives assigned to the local government, so it can be found indicators to measure the extent to which objectives have been achieved. That is, these indicators can be used in conjunction with economic and financial indicators of more traditional and so easily understood by the public.
\end{abstract}

Keywords: accountability, accounting, information systems

\begin{abstract}
ABSTRAK
Reformasi akuntansi di sektor publik bertujuan untuk meningkatkan kualitas informasi yang diberikan kepada para pembuat keputusan dan stakeholder. Peningkatan kualitas informasi perlu dilakukan untuk mendorong akuntabilitas dan kinerja dalam organisasi sektor publik. Hal ini penting mengingat informasi akuntansi memainkan peran kunci dalam pengambilan keputusan pada organisasi. Studi ini bertujuan untuk mengetahui "bagaimana informasi akuntansi dimaknai oleh masyarakat dan pemerintah daerah Kabupaten Gowa dalam konstruksi akuntabilitas publik". Studi ini melibatkan metodologi interpretif yang menggunakan cara pandang para nominalis dari paham nominalism yang melihat realitas sosial sebagai sesuatu yang tidak lain adalah label, nama, atau konsep yang digunakan untuk membangun realitas. Para nominalis memandang bahwa sesungguhnya tidak ada sesuatu yang nyata. Nama-nama hanya dianggap sebagai kreasi artifisial yang kegunaannya tergantung pada kesesuaian untuk mendeskripsikan, memberikan arti, dan menegosiasi sesuatu atau dunia luar. Studi ini menemukan bahwa pemerintahan kabupaten Gowa belum melakukan upaya sukarela untuk menyesuaikan model pengelolaan dan pelaporan mereka dengan kebutuhan khas akuntabilitas sektor publik. Penyesuaian semacam ini seharusnya dimulai dari pendefinisian dengan jelas tujuan yang ditugaskan pada pemerintah daerah, sehingga dapat ditemukan indikator untuk mengukur sejauh mana tujuan telah tercapai.
\end{abstract}


Artinya, indikator ini dapat digunakan bersamaan dengan indikator ekonomi dan keuangan yang lebih tradisional sehingga mudah dipahami olah masyarakat.

Kata kunci: akuntabilitas, akuntansi, sistem informasi

Social science must be critical of its object. In order to be able to explain and understand social phenomena, we have to examine them critically (Sayer dikutip dalam Aveh, 2013: 5)

\section{PENDAHULUAN}

Reformasi akuntansi di sektor publik bertujuan untuk meningkatkan kualitas informasi yang diberikan kepada para pembuat keputusan dan stakeholder. Peningkatan kualitas informasi perlu dilakukan untuk mendorong akuntabilitas dan kinerja organisasi sektor publik. Hal ini penting mengingat informasi akuntansi memainkan peran kunci dalam pengambilan keputusan, dan penggunaan informasi yang lebih relevan pada manajemen sektor publik dapat meningkatkan akuntabilitas organisasi.

Akuntansi, sistem informasi dan akuntabilitas merupakan tiga kata yang memiliki peran penting dalam reformasi sektor publik di Indonesia yang dimulai sejak tahun 1990 an. Reformasi tersebut tampak dengan adanya berbagai perubahan demi perubahan terhadap aturan perundang -undangan atas akuntansi, sistem informasi dan akuntabilitas yang mengarah kepada good governance. Sebagaimana tampak pada pengenalan metode akuntansi baru, seperti manajemen yang berorientasi pada tujuan dengan mendorong diterapkannya model akuntansi akrual (PP No. 24 tahun 2005 disempurnakan oleh PP No. 71 tahun 2010); perubahan model akuntabilitas yang dikenal dengan "triple accountability" (termuat dalam Peraturan Pemerintah No.3 tahun 2007 tentang Laporan Pemerintah Daerah); dan diterapkannya sistem informasi keuangan daerah (SIKD) yang on-line dan transparan untuk semua pemerintah daerah di Indonesia. Hal ini merupakan konsekuensi dari peningkatan otonomi keuangan pemerintah daerah Indonesia. Secara khusus, reformasi memodifikasi sistem akuntabilitas dalam upaya menghindari akuntabilitas sewenangwenang dan samar-samar, melalui cara-cara yang lebih manajerial, sehingga lebih transparan.

Reformasi sektor publik di Indonesia, seperti di negara lain, berusaha untuk menyebarkan konsep akuntabilitas manajerial yang melibatkan para pimpinan dengan output tertentu, dan/atau penggunaan sumber daya untuk mencapai tujuan yang di tentukan. Namun, saat ini hanya sedikit bukti empiris yang menunjukkan hubungan pengembangan akuntansi, sistem informasi dan akuntabilitas pada pemerintahan daerah Indonesia. Studi empiris yang ada hanya menegaskan kesulitan kelembagaan dalam mengarahkan reformasi manajerial, dalam konteks pemerintah daerah Indonesia. Namun, belum ada studi khusus yang memahami peran akuntansi, sistem informasi dan akuntabilitas dalam konteks reformasi pemerintahan daerah.

Studi ini berharap bahwa setelah lebih dari dua dekade reformasi, prinsip manajerialisme telah menyebar dan dipahami baik oleh para pimpinan (eksekutif) maupun masyarakat daerah secara menyeluruh. Manajer, dalam hal ini, lebih bertanggung jawab dan akuntabel, serta berusaha untuk mengembangkan akuntansi dan sistem informasi yang lebih akurat. Pada saat yang sama, akuntansi dan sistem informasi dapat membantu manajer untuk memenuhi aktivitas pengendalian dan kebijakan, serta akuntabilitas. Di sisi lain, akuntansi dan sistem informasi yang tertuang dalam akuntabilitas pemerintah daerah dapat diterima oleh stakeholder sesuai dengan harapan mereka, tanpa menimbulkan konflik di antara mereka.

Pertimbangan kedua dari pentingnya penelitian ini adalah isi dari pertanggungjawaban itu sendiri. Dalam hal ini, Stewart, 
salah seorang yang memformulasikan model akuntabilitas sektor publik pada tahun 1984, mengemukakan bahwa akuntabilitas di organisasi publik terdiri atas lima yaitu: (1) akuntabilitas kebijakan; (2) akuntabilitas pro gram; (3) akuntabilitas kinerja; (4) akuntabilitas proses; dan (5) akuntabilitas kejujuran dan legalitas. Menurutnya, akuntabilitas kejujuran dan legalitas berkaitan dengan upaya untuk menghindari penyimpangan jabatan dan ilegalitas. Akuntabilitas proses berkaitan dengan kepastian bahwa prosedur telah sesuai dan efisien, sementara, akuntabilitas kinerja berkaitan dengan pencapaian standar yang telah ditetapkan. Sedangkan, akuntabilitas program berkaitan dengan pencapaian tujuan dan sasaran, dan model akuntabilitas Stewart yang terakhir adalah akuntabilitas kebijakan yang berkaitan dengan tujuan dan sasaran dari kebijakan itu sendiri.

Sistem informasi akuntabilitas sebaiknya memenuhi semua model akuntabilitas yang diajukan Stewart, karena model tersebut menyajikan sistem informasi baik informasi keuangan maupun non-keuangan, seperti output dan outcome informasi. Menurut Stewart (1984), pada tingkat yang lebih tinggi dari akuntabilitas, sistem akan lebih peduli dengan informasi kualitatif dibandingkan dengan informasi kuantitatif, juga lebih mementingkan informasi strategis daripada informasi operasional.

Oleh karenanya, pemahaman akuntansi dan sistem informasi yang menghasilkan sistem akuntabilitas perlu ditinjau dari berbagai sudut pandang, yaitu dari accountor (dalam hal ini pemerintah daerah) ke accountee (stakeholder). Hal ini disebabkan karena beragamnya stakeholder yang berkepentingan dengan akuntabilitas pemerintah dan, karenanya, masing-masing accounttees dengan kepentingan yang berbeda atas hasil kegiatan sektor publik perlu diakomodir. Perlu dipahami bahwa hubungan antara accountor dan accountee jauh lebih luas daripada hubungan pemegang saham dan manajer konvensional.
Hal-hal yang perlu dicermati ketika membangun sistem akuntabilitas adalah kebutuhan untuk memenuhi hubungan akunta bilitas yang berbeda. Tampaknya terdapat tiga hubungan yang perlu diperhatikan dalam suatu organisasi (Hoopwood dan Tomkins, 1984; Goddard dan Powell, 1994). Yang pertama adalah hubungan administrasi/birokrasi/hirarkis, yang merupakan domain dari manajemen dan membutuhkan informasi dari indikator akuntansi/kinerja, dalam hal ini lebih bersifat praktek dari organisasi. Yang kedua adalah hubungan profesional yang mempertimbangkan profesional/klien, di mana dalam hubungan ini lebih memerlukan informasi tentang keberhasilan pelayanan. Yang ketiga adalah hubungan sosial/masyarakat, yang membutuhkan informasi kualitatif yang bersifat lebih informal. Pertimbangan lain dalam membangun sistem akuntabilitas adalah kebutuhan evaluasi dan penilaian dari informasi, serta konsekuensi dari tindakan (hukuman) sebagai bagian dari pengembangan akuntansi dan sistem informasi.

Sebagaimana pemerintah daerah (pemda) Kabupaten Gowa, yang menjadi objek penelitian, telah mengalami banyak perubahan, didorong oleh beberapa inisiatif reformasi. Salah satu "pilar" dari reformasi direpresentasikan oleh perubahan dalam sistem akuntansi. Akuntansi pemerintah daerah (pemda) Kabupaten Gowa telah secara tradisional menjadi sebuah dasar kewajiban dan berfokus pada pemenuhan akuntabilitas di mana pada 3 tahun terakhir (2009 sampai dengan 2012), pemda Gowa telah mengadopsi sistem akuntansi kas menuju akrual (cash toward accrual). Sebagai sebuah konsekuensi, pemda Gowa secara perlahan mulai mengembangkan sistem akuntansi mereka dan telah mengalami sebuah proses berkelanjutan, dengan mengadaptasi sistem akuntansi keuangan yang lebih moderen (berbasis teknologi yang dikenal dengan "SAK") agar dapat mengembangkan sistem informasi akuntansi yang lebih berkualitas (Damayanti et al., 2012). Selain itu, Damayanti et al. (2012) juga menemukan 
bahwa organisasi ini menginternalisasikan budaya Makassar dalam pengembangan sistem pemerintahan yang sarat dengan kearifan lokal.

Studi ini bertujuan menindaklanjuti penelitian terdahulu untuk mengetahui "bagaimana akuntansi dan sistem informasi dimaknai oleh masyarakat dan pemerintah daerah Kabupaten Gowa dalam mengkonstruksi akuntabilitas publik". Temuan studi ini dapat memberikan kontribusi terhadap bidang keilmuan akuntansi pemerintahan, khususnya yang berkaitan dengan akuntansi, sistem informasi dan sistem akuntabilitas. Hal ini disebabkan karena, studi ini meneliti makna akuntansi dan sistem informasi dari sudut pandang accountor (dalam hal ini pemerintah daerah) dan accountee (stakeholder) setelah beberapa tahun berlangsungnya reformasi sektor publik. Berdasarkan pemaknaan dari masingmasing aktor, maka dapat diketahui peran akuntansi dan sistem informasi yang dihasilkan oleh pemerintah daerah. Selanjutnya, studi ini membangun sebuah model sistem akuntabilitas berdasarkan perspektif lokal yang sesuai dengan kebutuhan stakeholder.

\section{METODE PENELITIAN}

Penelitian ini dilaksanakan pada masyarakat dan pemerintah daerah di Kabupaten Gowa Provinsi Sulawesi Selatan dengan mengadopsi kerangka kerja teoretis dari literatur akuntansi, sistem informasi, akuntabilitas, dan reformasi sektor publik. Desain penelitian menggunakan pendekatan kualitatif di mana pengumpulan data dilakukan melalui metode triangulasi dan kualitatif (yaitu observasi langsung, interview mendalam, analisis dokumen, dan lainnya), selama kurang lebih 8 bulan. Hasil penelitian dengan pendekatan kualitatif diharapkan dapat menggambarkan rantai yang hilang antara akuntansi, sistem informasi, keputusan manajemen dan pengendalian, serta akuntabilitas. Secara khusus, akuntansi dan sistem informasi tampaknya memainkan peran penting baik dalam pengembangan manajerialisme maupun untuk tujuan akuntabilitas, meskipun keterbatasan teknologi dan organisasi ditemukan ketika mempelajari pemerintah daerah. Kondisi ini telah lama disadari oleh Sinclair (1995), sehingga ia membenarkan adanya beberapa makna dalam penggunaan akuntansi untuk tujuan akuntabilitas, dan perlunya pendekatan sistemik pada organisasi sektor publik ketika menghadapi reformasi akuntansi dan akuntabilitas.

Studi ini meggunakan metodologi interpretif, yang menggunakan cara pandang para nominalis dari paham nominalism yang melihat realitas sosial sebagai sesuatu yang tidak lain adalah label, nama, atau konsep yang digunakan untuk membangun realitas. Para nominalis memandang bahwa sesungguhnya tidak ada sesuatu yang nyata. Nama-nama hanya dianggap sebagai kreasi artifisial yang kegunaannya tergantung pada kesesuaian untuk mendeskripsikan, memberikan arti, dan menegosiasi sesuatu atau dunia luar.

\section{TINJAUAN TEORETIS}

\section{Akuntansi dan Informasi}

Beberapa tahun terakhir, walaupun tidak banyak, studi mengenai penggunaan informasi akuntansi yang dihasilkan dari basis akrual telah dilakukan di berbagai negara (Jones dan Puglisi, 1997; Ellwood dan Wynne, 2003). Banyak yang mengaitkan trend ini sebagai bagian dari New Public Management (NPM) atau New Public Financial Management (NPFM) di mana sering juga mewakili kasus legitimasi dan mekanisme isomorfis. Reformasi sektor publik, di bawah label NPM atau NPFM, berupaya untuk meningkatkan kinerja pemerintah dengan menekankan pada perlunya pengukuran kinerja sebagai alat untuk pengambilan keputusan, serta pentingnya manajerialisme administrasi publik dan akuntabilitas.

Hal ini disebabkan karena pengambilan keputusan merupakan tugas yang berat, sebagaimana diketahui oleh semua orang berdasarkan pengalaman pribadi. Dalam banyak kasus keraguan merupakan bencana 
karena dapat membuat suatu keputusan yang salah, oleh sebab itu, perencanaan atas kegiatan sangat diperlukan. Apalagi manajemen dalam kesehariannya dihadapkan pada permasalahan berkaitan dengan pengambilan keputusan alternatif, terutama apabila sumber daya yang tersedia relatif langka dan terbatas. Berdasarkan hal itu, maka informasi akuntansi yang relevan diperlukan untuk membuat keputusan dengan baik dan akurat, yang dapat memaksimalisasi manfaat, dan mengoptimalkan pemanfaatan sumber daya langka dan terbatas.

Akuntansi dan informasi yang dihasilkan tidak hanya diperlukan untuk evaluasi masa lalu dan menjaga kondisi organisasi saat ini, namun juga bermanfaat dalam perencanaan masa depan. Sebagaimana dikatakan Mbanefo yang dikutip oleh Nnenna (2012: 53) "this planning we may conventionally call budget/budgeting targets, which give meaning and direction to operations of the organization within a defined period. At the end of the budget period the external results are compared with budgeted performance and discrepancies (variance) are analyzed for purposes of exposing the causes so as to prevent reoccurrence". Anggaran mengungkap potensi permasalahan sebelum terjadi, dan mengkoordinasikan kegiatan seluruh organi sasi melalui pengintegrasian rencana dan tujuan dari setiap bagian organisasi. Anggaran juga memastikan bahwa rencana dan tujuan dari masing-masing bagian tersebut konsisten dan sejalan dengan tujuan luas organisasi. Oleh karenanya, seorang pim pinan didorong untuk berpikir ke depan sebelum menyetujui perencanaan yang di buat oleh masing-masing bagian tersebut, di mana pada akhirnya tujuan ditetapkan dan berfungsi sebagai tolok ukur untuk evaluasi kinerja selanjutnya. Jadi, penting bagi suatu organisasi pemerintahan memahami akuntansi dan system informasi yang dihasilkan, serta peranannya dalam setiap detail aktivitas organisasi tersebut.

\section{Peran Akuntansi dan Sistem Informasi dalam Organisasi Publik}

Studi empiris awal berkaitan dengan peran informasi akuntansi dilakukan oleh Simon dan kawan-kawan pada tahun 1954. Mereka membedakan tiga manfaat utama penggunaan informasi akuntansi yaitudigunakan sebagai scorecard (dalam hal ini mengidentifikasi perbedaan-perbedaan dari rencana), digunakan untuk menghasilkan informasi yang mengarahkan (khusus fokus pada area atau daerah yang membutuhkan pertimbangan lebih seksama), dan digunakan sebagai pemecahan masalah (memilih di antara berbagai alternatif). Contoh lain peranan informasi akuntansi dari pendekatan konvensional, yaitu penggunaan informasi akuntansi sebagai evaluasi kinerja manajerial (membangun suatu Reliance on Accounting information for Performance Measures, RAPM), di mana fungsi ini menjadi debat berkepanjangan yang dimulai oleh Hopwood pada tahun 1972 dan Otley tahun 1978. Mereka berdua dan para pengikutnya membahas tiga model utama penggunaan informasi akuntansi yaitu model akan kesadaran laba (profit conscious style), model pembatasan anggaran (budget constrained style), dan model penggunaan informasi untuk non-akuntansi (the non-accounting style). Model-model ini berbeda dalam dua hal yaitu apakah informasi akuntansi digunakan dalam setiap evaluasi kinerja manajer, dan jika digunakan, maka seberapa besar pengaruh dan penekanan informasi tersebut dalam evaluasi (Gårseth-Nesbakk dan Paulsson, 2012).

Perbedaan lain atas penggunaan informasi akuntansi dikemukakan oleh Mellemvik et al. (1988), dalam artikel mereka tentang fungsi akuntansi. Mereka membedakan dua fungsi utama penggunaan informasi akuntansi yaitu untuk pengelolaan sumber daya (tujuan akuntabilitas), dan untuk pengambilan keputusan (tujuan pengambilan kebijakan). Selain itu, mereka juga membahas tentang fungsi yang anomali dari akuntansi dikenal sebagai "accounting in action", tetapi pembahasan ini sebagian besar berhubu- 
ngan dengan pengaruh dari akuntansi (seperti memberikan legitimasi, fokus pada konflik atau menyelesaikan konflik) (Gårseth-Nesbakk dan Paulsson, 2012).

Sementara, Feldman dan March pada tahun 1981 membahas penggunaan informasi dalam organisasi yang juga ada relevansinya dengan bidang akuntansi, biasa disebut pengumpulan dan konsumsi informasi. Mereka menemukan bahwa sebagian besar informasi yang dikumpulkan dan dikomunikasikan memiliki relevansi kecil dalam keputusan. Informasi yang digunakan untuk menjustifikasi keputusan sering dikumpulkan dan diinterpretasikan ex-post (setelah keputusan) (Gårseth-Nesbakk dan Paulsson, 2012). Artinya, sebagian besar informasi yang dikumpulkan tidak dipertimbangkan dalam pengambilan keputusan. Terlepas dari informasi yang tersedia saat awal keputusan diambil, ternyata permintaan akan informasi juga semakin banyak. Kesenjangan informasi sering menjadi keluhan bagi organisasi, sementara informasi yang tersedia diabaikan oleh organisasi. Relevansi informasi yang tersedia dalam pengambilan keputusan kurang dapat dibuktikan apabila dibandingkan dengan kebutuhan atau desakan akan informasi tambahan. Oleh karena itu, Feldman dan March (1981 dalam Gårseth-Nesbakk dan Paulsson, 2012) menyimpulkan bahwa terdapat konsumsi berlebihan atas informasi dalam organisasi.

Pada akhirnya Hansen (2005 dalam Gårseth-Nesbakk dan Paulsson, 2012), meneliti penggunaan informasi akuntansi pada dua perusahaan dan menemukan bahwa penggunaan informasi akuntansi tidak mengikuti pandangan tradisional penggunaan akuntansi dan pengguna, seperti yang sering diasumsikan dalam literatur akuntansi. Dengan mengamati informan dari waktu ke waktu, Hansen menemukan bahwa informan pada dasarnya menggunakan informasi akuntansi, tetapi tidak dengan cara konvensional. Sebaliknya, informan sangat mengandalkan model kognitif yang terdapat pada angka-angka akuntansi utama, di mana mengarahkan pada aturan praktis tertentu yang dapat digunakan sebagai dasar untuk pengambilan keputusan mereka. Kontribusi penelitian Hansen mengikuti studi-studi akuntansi terdahulu, misalnya Dillard (1984), Peters (1993), Kida dan Smith (1995), serta Libby dan Bloomfield (2002). Para peneliti terdahulu tersebut telah membahas tentang model akuntansi kognitif, namun berbeda fokus. Sedangkan, Hansen melakukan studi longitudinal dengan pendekatan kualitatif, rujukan kontri butor lainnya lebih mengandalkan pada analitikal, kuantitatif dan beberapa desain penelitian dengan studi eksperimental yang berfokus pada topik-topik seperti representasi memori, memory coding, dan pengolahan informasi.

Di sisi lain, peran sistem informasi dan akuntansi dalam organisasi publik (khususnya, pemerintahan) baru mengalami perkembangan dengan adanya kecenderungan beberapa penelitian yang terdapat dalam literatur akuntansi. Objek studi yang dibahas dalam literatur tersebut memiliki topik yang berbeda-beda, seperti fungsi, tujuan, dan penggunaan akuntansi, serta topik lainnya, namun demikian, mereka semua berhubungan dengan peran informasi dalam akuntansi. Hal ini memungkinkan saya untuk mendapat gambaran yang holistik mengenai definisi penggunaan akuntansi dan sistem informasi yang sangat luas. Dalam literatur pun dibahas mengenai pertimbangan setiap situasi di mana akuntansi dan sistem informasi, baik secara langsung maupun tidak langsung, mempengaruhi keputusan atau aktivitas sebuah organisasi.

Menurut Borgonovi dan Anessi-Pessina (1998: 13), dalam rangka pemerintah daerah menyerap interpretasi nilai-nilai bisnis, maka sistem informasi harus mampu memberikan tiga unsur nilai, yaitu:

(a) an indicator system for the qualitativequantitative determination of the needs to satisfy and the satisfaction level achieved by the local government; (b) a planning and control system of the resources directed to the fulfilment of the objectives 
(qualitative and quantitative determination of the employments) and the resources absorbed for their coverage (qualitative and quantitative determination of the sources); (c) an analytic accounting system for the control of the results achieved in relation with the resources spent in order to improve efficiency.

Penelitian Borgonovi dan AnessiPessina di atas memberikan contoh mengenai cara-cara penggunaan akuntansi yang digambarkan dalam berbagai literatur. Selama tahun-tahun terakhir, beberapa studi lebih spesifik fokus pada penggunaan informasi kinerja dalam organisasi sektor publik. Misalnya, TerBogt (2004) membedakan penggunaan informasi kinerja dalam kelompok sangat sedikit/tidak ada yang menggunakan informasi; sedikit; tidak sering/tidak sedikit informasi yang mereka gunakan; dan kelompok yang sering dan sangat sering menggunakan informasi. Akhirnya, Jansen (2008) mengembangkan skala pengu- kuran terhadap para politisi dan birokrat berkaitan dengan penggunaan informasi kinerja pada tiga pemerintah daerah di Belanda. Dari hasil penelitiannya, ia menge- lompokkan politisi dan birokrat ke dalam beberapa kelompok yaitu kelompok yang tidak membaca informasi kinerja; hampir tidak menggunakan informasi; dan kelompok yang menggunakan informasi sebagai referensi, membacanya, dan melakukan analisis mendalam.

Hoque dan Adams (2011) menggabungkan pendekatan yang dilakukan oleh beberapa peneliti di atas. Mereka ingin melihat sejauh mana informasi pengukuran kinerja digunakan dalam beberapa fase yang berbeda dalam proses pengendalian manajemen, misalnya, formulasi anggaran, strategi perencanaan, dan pemberian reward. Selain dimensi di atas, mereka juga mengamati penggunaan informasi ukuran kinerja yang dikomunikasikan kepada para stakeholder eksternal.

Berdasarkan beberapa rujukan di atas, maka saya kembali pada objek penelitian, di mana selama dekade terakhir pemerintah daerah (pemda) Kabupaten Gowa telah mengalami sebuah proses reformasi, melibat kan perubahan mendalam pada sistem akuntansi mereka. Implementasi beragam atas reformasi di pemda tersebut dipengaruhi oleh reformasi sektor publik di pemerintahan daerah Indonesia. Perubahan secara umum diinspirasi oleh manajerialisme dan prinsip good governance, di mana aspek mendasar dari reformasi ini direpresentasikan oleh inovasi-inovasi dalam tehnik akuntansi dan akuntabilitas. Seperti yang telah digambarkan di beberapa negara maju oleh Hood (1995), dan Guthrie (1998), yang kemudian lebih dipertegas lagi oleh Caccia dan Steccolini (2006), dengan mengatakan bahwa akuntansi menyebabkan terjadinya perubahan budaya di organisasi publik.

Oleh karena itu, sistem informasi dan akuntansi memainkan sebuah peran sentral dan konstitutif dalam reformasi manajemen publik yang baru. Sistem ini mempengaruhi persepsi para aktor organisasional dan berkontribusi pada penyebaran budaya kuantifikasi dan rasionalisme dalam dunia pemerintahan. Sistem ini juga dapat membentuk visi realitas yang dimiliki para aktor organisasional, menyebarkan konsep seperti value for money, akuntabilitas, efektivitas, efisiensi, yang mengubah mereka ke dalam makna dan nilai-nilai baru. Pada saat yang sama, budaya aktivitas rutin akuntansi yang sudah ada, boleh jadi membatasi proses perubahan, sehingga membawa pengaruhi negatif terhadap pelaksanaan sistem dan prosedur akuntansi yang baru. Dalam hal ini, SAK (sistem akuntansi keuangan), yang dimaksudkan sebagai mesin untuk menghasilkan akuntabilitas telah dikembangkan oleh pemda Gowa, namun sekali lagi sistem ini telah efektif dalam merubah budaya kerja. Hal ini disebabkan sistem tersebut telah dibangun berdasarkan landasan kebutuhan, kemampuan, serta budaya lokal yang dimiliki oleh lingkungan organisasi (Damayanti et al., 2012). Meski demikian, studi ini menemukan bahwa pola pertanggungjawaban yang dilaksanakan dalam sistem akuntabilitas ini tidak disertai dengan 
jaringan arus yang dapat menghantarkan informasi sampai ke akar rumput.

\section{Akuntabilitas: Refleksi Akuntansi dan Sistem Informasi}

Akuntabilitas dipandang sebagai kapasitas dan keinginan individu untuk membuat sebuah pernyataan, penjelasan atau alasan sehubungan dengan apa yang dilakukan oleh individu tersebut, atau dalam arti proses, merupakan tuntutan dan pemberian alasan atas suatu tindakan. Sebagaimana Giddens (1984:30) mengatakan bahwa untuk mempertanggungjawabkan satu aktivitas, seseorang membutuhkan dua hal yaitu, "to explicate the reasons for them and to supply the normative grounds whereby they may be "justified". Norma yang berlaku untuk kedua hal tersebut, umumnya, didasarkan pada wacana dan narasi menurut pandangan Ezzamel et al. (2007).

Akuntabilitas juga dapat dipandang sebagai produk dari hubungan otoritarian di mana garis tindakan digambarkan secara hati-hati. Definisi tergantung pada 'ideologi, motif dan bahasa' yang digunakan dan memiliki makna yang spesifik terhadap disiplin ilmu tertentu, oleh karenanya 'the more definitive we attempt to render the concept, the more murky it becomes' (Sinclair, 1995:221). Dalam arti yang lebih spesifik, akuntabilitas banyak didefinisikan sebagai fungsi pencatatan/pelaporan atau menyiratkan penjelasan atau pembenaran atas tindakan. Beberapa pakar telah menjelaskan maknanya menurut istilah legalistik, namun oleh pihak lain dianggap sebagai suatu konsep yang kurang memberikan suatu definisi yang jelas. Seperti Vosselman (2012), menggambarkan akuntabilitas sebagai hubungan sosial yang memiliki baik dimensi moral maupun strategis dan dapat dipahami sebagai sesuatu yang dirasakan seseorang atau bahkan dijadikan sarana pengawasan.

Pada dasarnya, penekanan utama di sini adalah informasi yang menjadi titik perdebatan dan diskusi para ahli. Oleh karenanya, Jackson (dalam Stewart, 1984: 14) berpendapat bahwa,
Basically, accountability involves explainning or justifying what has been done, what is currently being done and what has been planned. Accountability arises from a set of established procedures and relationship of varying formality. Thus, one party is accountable to another in the sense that one of the parties has the right to call upon the other to give an account of his activities. Accountability involves, therefore the giving of information.

Jadi, pandangan di atas merupakan konsep terbatas dari akuntabilitas yang hanya meliputi penyediaan informasi. Dunsire (dalam Stewart, 1984: 14), di sisi lain, mendefinisikan akuntabilitas lebih jauh, yaitu:

Being accountable may mean as is now said about ministerial responsibility, no more than having to answer quetions about what has happened or is happening within one's jurisdiction ... But most usages require an additional implication: the answer when given, or the account, when rendered, is to be evaluated by the superior or superior body, measured against some standard or some expectation, and the difference noted; and then praise or blame are to be meted out or sanction applied. It is the coupling of information with its evaluation and application of sanctions that gives 'accountability' or 'answerability' or 'responsibility' their full sense in ordinary organisational usage.

Berkaitan dengan pernyataan di atas, penggunaan umum akuntabilitas, karenanya, melibatkan informasi (dan tidak hanya informasi keuangan), serta evaluasi atas informasi tersebut, kemudian apresiasi atau koreksi atas tindakan yang dilakukan.

Meskipun terdapat beragam definisi akuntabilitas yang telah dibahas di atas, namun secara umum diakui bahwa definisi akuntabilitas pada organisasi publik melibatkan dua elemen kunci menurut Stewart (1984), (1) The account dan the holding to account, (2) Dua pihak-the accountor (or 'agent' or 'one who accounts and is held to account') and the accountee (or 'principal' or 'one whoholds to account'). 
Sebagaimana tampak pada gambar $1 \mathrm{di}$ bawah yang menunjukkan hubungan prinsi- pal (masyarakat) dan agen (pemerintah) dalam proses akuntabilitas.

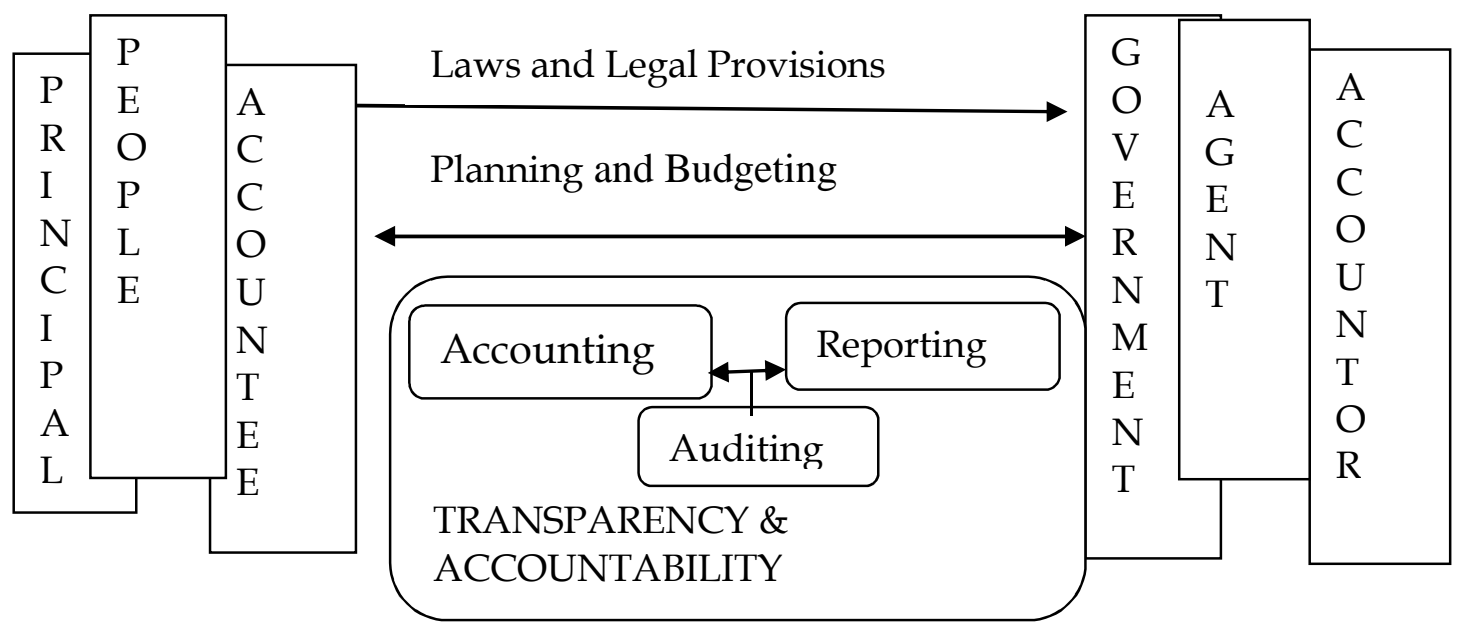

\section{Gambar 1}

Hubungan Prinsipal-Agen dalam Organisasi Pemerintahan

Sumber: hasil modifikasi dari Manao dan Martani (2009)

Dalam hal ini, accountee memiliki hak untuk meminta informasi kepada accountor, sementara accountor mempunyai tanggung jawab untuk memberikan informasi tersebut. Hubungan di antara kedua belah pihak dapat digambarkan sebagai hubungan pelayanan di mana accountor menerima amanah yang dipercayakan kepadanya, dan sebagai gantinya memberikan penghargaan yang memuaskan keinginan accountee sebagai hasil dari pelaksanaan tugas pelayanan.

Sementara, permasalahan menjadi rumit pada organisasi pemerintahan karena tujuan lebih mengarah pada faktor sosial dan politik ketimbang ekonomi. Dalam masyarakat demokrasi, penerimaan atas tujuan (dan arahan pimpinan atas alokasi sumber daya), dihasilkan melalui proses demokrasi. Jadi, dapat dikatakan bahwa akuntabilitas organisasi sektor publik terletak antara organisasi dan negara, oleh karenanya menjadi tugas bagi politisi untuk memastikan bahwa akuntabilitas dilaksanakan oleh mereka yang dipercaya untuk mengelola organisasi dan negara atas nama kepentingan publik. Sebagaimana tampak pada gambar 2 yang merupakan tiga rangkai model akuntabilitas.

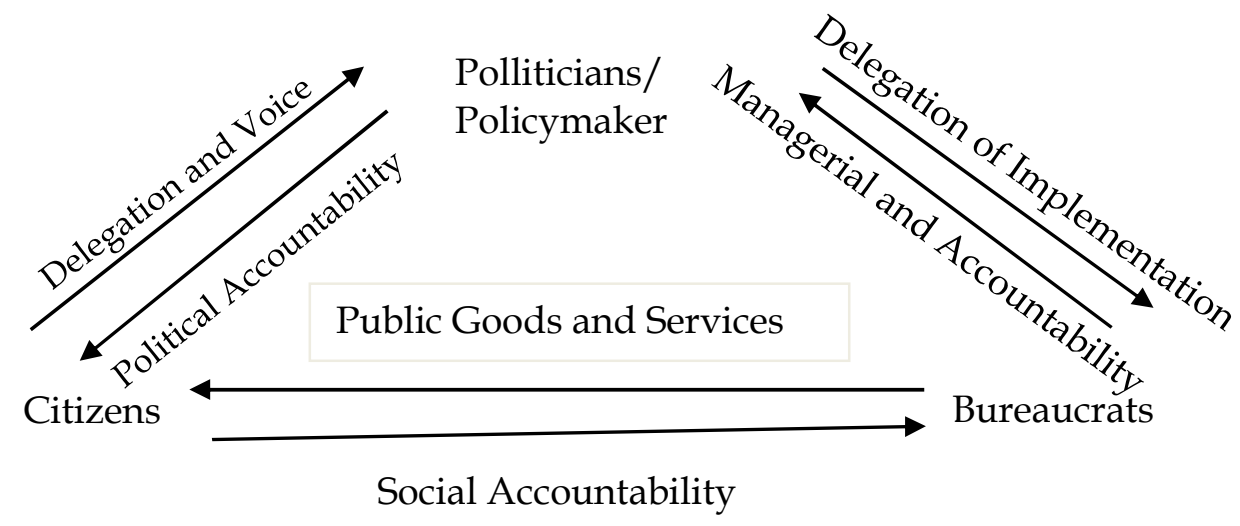

Gambar 2

Sumber: Campos (2007)

The Accountability Triad 
Oleh karena itu, akuntansi dan sistem informasi harus mampu menyediakan informasi yang terefleksi di dalam model-model akuntabilitas di atas yaitu akuntabilitas manajerial, akuntabilitas sosial dan akuntabilitas politik. Jadi, pergeseran perhatian dari akuntansi menjadi akuntabilitas memerlukan pergeseran fokus dari akuntansi sebagai teknologi beralih fokus ke akuntansi sebagai praktek sosial dan kelembagaan. Peralihan ini membawa mekanisme manajemen sosial dan ekonomi ke dalam fokus yang menciptakan 'governable persons' atau memperhitungkan segala hal, meliputi 'the audit society' sebagaimana dikutip oleh Vosselman (2012) dari beberapa literatur terdahulu.

Walaupun, gagasan akuntansi dan sistem informasi sedikit terlambat dicermati oleh para pakar. Namun, sejumlah studi telah mencoba untuk memahami peran akuntansi dan sistem informasi dalam berkontribusi terhadap tata kelola organisasi di pemerintahan. Dalam hal ini, penekanan utama terletak pada cara-cara di mana teknologi akuntansi mampu memfasilitasi tindakan pemerintah secara nyata, sebagaimana yang dikemukakan oleh Miller dan Rose (dalam Neu, 2000: 270),

We use the term 'technologies' to suggest a particular approach to the analysis of the activity of rulling, one which pays great attention to the actual mechanisms through which authorities of various sorts have sought to shape, normalize and instrumentalize the conduct, thought, decisions and aspirations of others in order to achieve the objectives they consider desirable.

Kutipan di atas jelas menunjukkan bahwa terminologi teknologi merupakan sebuah pendekatan untuk mengatur organisasi melalui sistem otoritas yang ada. Artinya, harus ada mekanisme untuk merumuskan masalah melalui mekanisme aspirasi.

Masalah-masalah dilaporkan secara transparan, dan solusi dibingkai melalui mekanisme umum seperti akuntansi dan sistem informasi. Tehnik-tehnik tersebut membutuhkan pengetahuan luas untuk me- mobilisasi hal-hal yang perlu dianalisis lebih lanjut. Karenanya, seperti peta, analisis akuntansi membangun sebuah citra tertentu, sehingga isu-isu penting akan mungkin untuk diselesaikan. Karakter dari intervensi ini dapat berbentuk regulatif dan distributif, di mana kebijakan/tujuan yang dioperasionalkan dengan tehnik akuntansi tidak hanya mengatur tindakan individu/kelompok, tetapi juga mendistribusikan kekayaan masyarakat secara keseluruhan (Neu, 2000).

Karenanya, akuntansi (termasuk sistem informasi) harus dijaga sedemikian rupa agar tetap menghargai nilai-nilai utama dari aktivitas pelayanan. Strategi ini bertujuan untuk menghindari konflik dan menimbulkan resistensi terhadap intervensi atas strategi yang biasanya berlebihan. Oleh karena itu, akuntansi dalam berbagai bentuknya, memberi jaminan atas pengendalian organisasi, mengurangi kompleksitas dan mengabaikan ambiguitas seperti adanya konsekuensi. Konsekuensi dari suatu ambiguitas tersebut ditransformasikan dalam angkaangka akuntansi dan non-akuntansi dalam bentuk berbagai model akuntabilitas.

Oleh karena itu, modifikasi akuntansi dan sistem informasi perlu dalam rangka membantu perubahan bentuk organisasi dan budaya, memberikan kontribusi bagi penyatuan berbagai simbol dan makna baru. Aktor organisasi pun dapat menggunakan alat akuntansi untuk mempromosikan, mengkonsolidasikan, serta mengubah persepsi dan nilai-nilai bersama, di samping itu, juga mendorong hubungan kekuasaan. Perubahan tersebut dibenarkan dengan alasan dapat mengurangi penyebab konflik politik dan budaya, sehingga, inovasi akuntansi yang menghasilkan sistem informasi yang handal bagi akuntabilitas pada organisasi publik terus mengalami perkembangan. Hal ini menyangkut interaksi para aktor dengan proses perubahan kelembagaan, budaya dan organisasi yang diberi label new public management.

Akuntansi dan sistem informasi yang dihasilkan tampaknya merupakan hal pokok 
dalam reformasi sektor publik, yang memainkan peran legitimasi dan konstitutif dalam proses perubahan, memengaruhi persepsi para pelaku organisasi, serta memfasilitasi dan membentuk perubahan. Namun demikian, pada saat yang bersamaan, retorika dan realitas reformasi akuntansi dapat beragam, misalnya, perubahan terjadi dengan lambat atau memberikan pengaruh yang tak terduga dan tidak diinginkan.

Walaupun demikian, akuntansi dan sistem informasi tetap memegang peranan penting dalam reformasi new public management (NPM), karena reformasi tersebut bertujuan untuk meningkatkan kualitas informasi yang diberikan kepada para pembuat keputusan dan stakeholder. Peningkatan kualitas informasi perlu dilakukan untuk mendorong akuntabilitas dan kinerja dalam organisasi sektor publik mengingat bahwa informasi akuntansi memainkan peran kunci dalam pengambilan keputusan pada organisasi (Pettersen, 2001). Berdasarkan reformasi akuntansi, maka pemerintah daerah Indonesia yang semula menganut sistem akuntansi anggaran tradisional berbasis kas dimana secara eksklusif berfokus pada input, kemudian mengalami transformasi menjadi focus pada output dengan sistem akuntansi akrual di mana implementasinya sesuai dengan sektor swasta. Perubahan ini merupakan pergeseran dari akuntabilitas-proses menuju pada akuntabilitas hasil.

Meskipun penerapan yang ketat atas sistem akuntansi akrual pada organisasi sektor publik bukan merupakan hal yang dianjurkan karena masalah pengukuran, kurangnya dukungan teoritis dan faktor peningkatan subjektivitas (Chan, 2003), namun, manfaat yang diharapkan melampaui kelemahannya. Oleh karenanya, pemerintah yang melakukan reformasi akuntansi mengalami peningkatan dalam akuntabilitas, seperti hasil temuan penelitian di Kabupaten Gowa.

Apalagi jika akuntansi dan sistem informasi dipadukan dengan sistem teknologi informasi (TI), sehingga dapat membantu pengelolaan dan pengendalian keua- ngan daerah. Fenomena tersebut tampak pada pemerintah daerah Gowa yang telah memiliki teknologi informasi, dikenal dengan istilah SAK (Sistem Akuntansi Keuangan). Kemajuan dalam bidang teknologi telah membuka kemungkinan menghasilkan informasi akuntansi yang strategis dan memudahkan dalam proses akuntabilitas. Di samping itu, sistem akuntansi juga berfungsi mengaitkan seluruh komponen dalam organisasi untuk mengumpulkan informasi, data mentah atau data biasa dan mengubahnya menjadi data keuangan untuk tujuan pelaporan (akuntabilitas) bagi pengambilan keputusan. Walaupun dalam kasus pemerintah daerah Gowa, akuntabilitas yang mereka lakukan hanya sebatas akuntabilitas keuangan dan kinerja saja sebagaimana yang diamanatkan dalam Undang-Undang No 17 tahun 2003 dan Peraturan Pemerintah No. 71 tahun 2010 (Damayanti et al., 2012).

Untuk lebih memahami istilah akuntansi dan sistem informasi, terdapat tiga kata yang merupakan kata kunci, di mana ketiganya akan diuraikan secara terpisah (Soudani, 2012). Pertama, beberapa literatur menyebutkan bahwa akuntansi dapat diidentifikasi menjadi tiga komponen, yaitu sistem informasi, "bahasa bisnis" dan sumber informasi keuangan. Kedua, informasi adalah pengolahan data berharga yang memberikan dasar untuk membuat keputusan, mengambil tindakan dan memenuhi kewajiban hukum. Komponen ketiga adalah sistem merupakan sebuah entitas yang terintegrasi, di mana kerangka kerja difokuskan pada serangkaian tujuan. Keuntungan utama dari penggunaan optimal akuntansi dan sistem informasi dalam suatu organisasi adalah organisasi dapat beradaptasi dengan lebih baik terhadap perubahan lingkungan, manajemen menjadi lebih baik dan tingkat daya saing menjadi tinggi.

Isu yang berkembang pada beberapa literatur adalah isu berkaitan dengan masalah pengaruh politik terhadap pilihan kebijakan akuntansi dan pertanyaan mendasar yang krusial adalah apakah politisi yang menyebabkan krisis akuntabilitas. Dalam hal 
ini, pengambilan keputusan dapat dipandang sebagai sebuah proses politik yang melibatkan banyak aktor dengan ketidakkonsistenan preferensi dan ditemukannya motif dalam tindakan mereka, jika dibandingkan dengan saat awal menyampaikan kebijakan (yaitu, rencana) (Lawton et al., 2000). Sebagaimana ungkapan Gerboth (di kutip dalam Pilcher, 2004: 3) bahwa "when a decision-making process depends for its success on public confidence, the critical issues are not technical; they are political ...".

Karenanya, Stewart (1984) memberikan perhatian yang lebih luas atas akuntabilitas. Dia berpendapat bahwa akuntabilitas dapat meningkatkan pentingnya akuntansi dan arus informasi, termasuk semua hal yang diungkapkan oleh akuntansi. Namun pada arena publik, informasi itu sendiri bukanlah merupakan tujuan akhir. Informasi hanya merupakan dasar untuk penilaian dan tindakan, tetapi akuntansi yang utama karena sumber informasi. Oleh karena itu, akuntansi membutuhkan basis yang efektif dalam menginformasikan segala hal untuk menjalankan akuntabilitas di arena publik. Berkaitan dengan hal di atas, Stewart (1984) menantang dan memprovokasi akuntansi di sektor publik untuk memberikan informasi berhubungan dengan review kebijakan, sebagaimana informasi yang diberikan dalam akuntabilitas manajerial (seperti, laporan kinerja, laporan keuangan). Akuntansi dapat digunakan secara lebih aktif untuk memfasilitasi proses politik di seputar pengambilan keputusan publik.

The American Accounting Association (AAA) (dalam Pilcher, 2004: 5), komite konsekuensi sosial dari informasi akuntansi, membuat pernyataan bahwa:

Every policy choice represents a trade-off among differing individual preferences, and possibly among alternative consequences, regardless of whether the policy makers see it that way or not. In this sense, accounting policy choices can never be neutral. There is someone who is granted this preference, and someone who is not.

Ungkapan di atas sejalan dengan pendapat yang menyatakan bahwa pilihan kebijakan hanyalah sebuah pilihan yang dilakukan oleh beberapa individu atau kelompok dalam memanfaatkan prosedur yang dianggap terbaik agar sesuai dengan keadaan tertentu. Seperti ungkapan Stempf (dalam Pilcher, 2004: 5) bahwa "financial statements are essentially the representations of management". Oleh karena itu, pilihan atas metode penilaian atau penyusutan tertentu, misalnya, dilakukan oleh manajemen untuk memenuhi kebutuhan pelaporan pada saat itu.

Pilcher (2004: 5), kemudian, menangkap adanya kompleksitas isu dari pembahasan tersebut. Dia menyimpulkan bahwa, seperti keputusan atas kebijakan publik lainnya, proses yang ditentukan oleh pilihan akuntansi dan pelaporan keuangan, termasuk perilaku individu dan interaksi kelompok, dibatasi oleh struktur politik dan birokrasi dalam konteks ruang lingkup yang lebih luas yaitu sosial-ekonomi dan partai politik. Sebagaimana temuan penelitian dalam literatur pilihan publik, inovasi penelitian dan inovasi institusional mengatakan bahwa konteks politik merupakan sesuatu yang sangat kompleks di mana kualitas informasi akuntansi dan pelaporan keuangan mungkin penting. Karenanya, pengaruh stakeholder khususnya 'kebutuhan' untuk responsif terhadap pengurangan kekuasaan tidak mudah tercapai, maka mengangkat isu kepada siapa, dalam hal ini pemerintah daerah, bertanggung jawab menjadi isu penting. Sebagai contoh, seorang manajer penjara mengatakan bahwa "ultimately the capacity to be 'responsive' is politically determined by control over inputs, structure, processes and types of output" (Lawton et al., 2000: 16).

\section{ANALISIS DAN PEMBAHASAN Kearifan Lokal: Internalisasi Budaya Organisasi Pemerintah Daerah}

Kebudayaan Makassar sebagai salah satu budaya lokal yang tetap eksis dari sekian banyak budaya lokal di Indonesia, mengajarkan konsep sipakatau, sirik dan pacce sebagai salah satu landasan budayanya. Sipakatau merupakan konsep yang meng- 
ajarkan manusia untuk melakukan interaksi sosial sesuai dengan nilai-nilai ideal kebudayaan. Sipakatau memiliki makna saling me-manusia-kan. Sementara, sirik (harga diri) dan pacce (pedih, iba) merupakan nilainilai budaya yang seharusnya ada pada setiap diri manusia. Jadi, untuk mencapai derajat manusia yang tinggi, maka setiap manusia dalam berinteraksi dengan manusia lainnya seharusnya menjaga sirik dan pacce yang terdapat dalam diri, serta memegang teguh konsep sipakatau.

Sebagai nilai luhur yang dianut oleh masyarakat Makassar budaya sirik telah dikenal luas oleh para pemerhati budaya seiring dengan perkembangan kerajaan Gowa dan Makassar sebagai pusat perdagangan di belahan Timur Indonesia. Konsep sirik sebagai sistem nilai budaya yang abstrak sangat sulit didefinisikan, karena ia hanya dapat dirasakan oleh penganut kebudayaan itu. Beberapa pandangan memberikan interpretasi yang berbeda-beda atas makna sirik. Errington sebagaimana dikutip oleh Wahid (1992) mengemukakan bahwa bagi masyarakat Bugis Makassar tidak ada tujuan atau alasan hidup lebih tinggi atau lebih penting selain menjaga sirik nya. Sementara, menurut Hamka dalam Wahid (1992) konsep sirik menimbulkan sikap tawadhu dan sikap yang terpuji yaitu mahmudah (suatu perbuatan mulia). Jadi, ia kemudian menyimpulkan bahwa menurut Islam konsep sirik erat kaitannya dengan orang yang beriman dan berakhlak tinggi.

Pandangan lain dikemukakan oleh Budidarmo yang dikutip oleh Wahid (1992: 75) bahwa, "... saya dapat mempelajari, bahwa sirik adalah pandangan hidup yang mengandung etika pembedaan antara manusia dan binatang, dengan adanya rasa harga diri dan kehormatan yang melekat pada manusia". Sirik, menurutnya mengajarkan moralitas kesesuaian berupa anjuran, larangan, hak dan kewajiban yang mendominasi tindakan manusia untuk menjaga dan mempertahankan harga diri dan kehormatan tersebut.

Apabila dicermati makna-makna di atas, maka sirik selain menimbulkan perasa- an halus dan suci, sirik juga dapat menimbulkan sikap perlawanan apabila harga diri dan kehormatannya dipermalukan. Oleh karena itu, konsep sipakatau ada untuk memelihara segi-segi positif dari konsepsi sirik, yang menjadi sendi utama kebudayaan di Sulawesi Selatan pada umumnya dan kebudayaan Makassar pada khususnya. Sirik adalah proses endapan kaidah-kaidah yang diterima dan berlaku dalam lingkungan masyarakat, mengalami pertumbuhan berabad-abad, sehingga membudaya dalam kehidupan kemasyarakatan.

Di samping konsep sirik, terdapat lagi konsep lain yang disebut pacce. Secara leksikal pacce berarti pedih, perih atau iba. Menurut Wahid (1992: 78), pacce dapat dimaknai sebagai rangsangan dari hati yang paling dalam untuk melakukan kebaikan atau menolong sesama manusia, seperti membantu orangtua jompo, membantu anak yatim. Jadi, secara umum saat ini saya memaknai pacce sebagai sifat altruistik yang ada pada diri manusia, dan makna tersebut dapat berbeda setelah saya melakukan studi lapang dan berbaur dengan masyarakat Makassar.

Masyarakat Makassar dalam melakukan interaksi sosial yang dipagari oleh sipakatau memiliki beberapa falsafah hidup yang mengandung makna sirik dan pacce, seperti: (1) sirik paccea ri katte baji ni alle olloyang jari padoman asi momballa ri lino (harga diri dapat dijadikan jalan, jadi pedoman melayari dunia ini); (2) sirik paccea ri katte punna rappang belo-belo si kamma cini si mamuji ngaseng (harga diri andaikan perhiasan, semua yang melihat akan memuji); dan (3) sirik paccea ri katte kontu balla ia bentengi ia patongko ia todong jari rinring (harga diri bagaikan rumah, dia juga atap dan juga dinding). Selain falsafah yang mengatur hubungan antara manusia dengan manusia, budaya Makassar juga memiliki filsafat hidup yang mengatur hubungan manusia dengan alam semesta, seperti: katutui bonena allanga na katutui tongko bonena langika mala birangnga naek gau (peliharalah 
isi dunia agar isi langit memeliharamu melebihi dirimu sendiri).

Demikianlah falsafah-falsafah hidup yang sangat berpengaruh dalam budaya Makassar yang perlu diangkat untuk disejajarkan dengan nilai-nilai kehidupan yang berasal dari budaya Barat. Menurut pandangan saya, konsep sipakatau, sirik dan pacce adalah merupakan kearifan lokal dan nilai transendental dari budaya Makassar yang dapat digunakan untuk membangun kembali tata hubungan kemanusiaan, baik antara individu maupun antara kelompok masyarakat, bahkan dalam membangun akuntansi, sistem informasi dan akuntabilitas yang baik di pemerintah daerah.

Berkaitan dengan akuntabilitas, adalah menarik untuk mengkaji dan memahami bagaimana pandangan masyarakat lokal dan pemerintah Kabupaten Gowa memaknainya. Alasannya adalah bahwa perhatian para pakar saat ini berkaitan dengan peran akuntansi dalam mencapai akuntabilitas, sering didasarkan pada definisi yang sangat sempit, dengan penekanan pada input daripada output, dan jarang mempertimbangkan dampak dan isu mengenai kesetaraan dan kearifan lokal (Goddard dan Powell, 1994). Selain itu, sedikit bukti yang menunjukkan akuntansi dan sistem informasi menggunakan bahasa budaya atau berkaitan dengan kebijakan.

Dalam hal ini dapat dilihat pada situs penelitian di mana Pemda Gowa dalam melakukan akuntabilitas seharusnya dipagari oleh sipakatau sebagai filsafat hidup yang mengandung makna sirik dan pacce, seperti: katutui bonena allanga na katutui tongko bonena langika mala birangnga naek gau (peliharalah isi dunia agar isi langit memeliharamu melebihi dirimu sendiri). Berkaitan dengan hal tersebut, tampak bahwa Pemda Gowa hanya memenuhi kepentingan menjaga "diri" dengan melaporkan apa yang mereka lakukan tanpa melihat kebutuhan "isi langit" atau apa yang dibutuhkan oleh masyarakatnya.

Sistem ini jarang melibatkan semua kelompok kepentingan, hanya memenuhi tingkatan rendah dari model akuntabilitas
Stewart. Dalam hal ini, sistem akuntabilitas umumnya berkonsentrasi pada hubungan akuntabilitas manajerial (managerial accounttability seperti akuntabilitas keuangan), dan jarang mempertimbangkan hubungan antara informasi yang dilaporkan dan tindakan yang diambil. Hal ini disebabkan karena model akuntabilitas tersebut menggunakan pendekatan objektivitas dalam pengembangan sistem. Pendekatan ini cenderung melihat akuntansi dan sistem informasi sebagai entitas yang terpisah dari konteks organisasi, akuntansi hanya dipandang sebagai bentuk untuk melaporkan informasi keuangan objektif saja. Pandangan ini membatasi ruang lingkup akuntansi yaitu sebatas laporan mengenai masalah keuangan, di mana hal ini dapat menimbulkan keengganan untuk menggunakan informasi yang lebih luas yaitu informasi kualitatif yang lebih bersifat subjektif. Pandangan objektif inilah yang mempersempit definisi akuntansi dan sistem informasi sebagaimana pengamatan dalam studi ini yang akan diuraikan lebih lanjut.

\section{Kewajiban Dasar: Akuntabilitas Perspektif Pemerintah Daerah}

Sebuah sistem informasi akuntabilitas sebaiknya memenuhi semua model akuntabilitas yang diajukan Stewart. Hal ini disebabkan karena keseluruhan model tersebut dapat menghasilkan sistem yang baik dalam melaporkan informasi keuangan, serta output dan outcome informasi. Menurut Stewart, pada tingkat yang lebih tinggi dari akuntabilitas, sistem akan lebih peduli dengan informasi kualitatif dibandingkan dengan informasi kuantitatif, juga lebih mementingkan informasi strategis dari pada informasi operasional.

Meskipun demikian, sebagaimana diketahui bersama bahwa pada sektor publik, untuk menunjukkan akuntabilitasnya, organisasi secara tradisional hanya bergantung pada informasi yang diberikan melalui laporan tahunan biasanya meliputi laporan keuangan, indikator kinerja utama, dan komentar 
manajemen. Seperti yang dikemukakan informan dari pemerintah daerah berikut ini:

Saya kira kalau laporan pemerintah, kita susun sesuai dengan program, sesuai dengan mekanisme dan jadwal yang ada. Jadi di sini, Alhamdulillah tidak pernah terlambat ... terkait dengan transparansinya. Saya kira Gowa ini salah satu juga daerah yang betul-betul menerapkan asas transparansi, dari sistem pengelolaan keuangannya bisa didapatkan dan mudah kita dapatkan melalui internet, ...

Jadi, dapat disimpulkan bahwa akuntabilitas pemerintah daerah pada dasarnya hanya memenuhi kriteria dasar dari model akuntabilitas Stewart yaitu managerial accounttability (seperti akuntabilitas keuangan). Dalam hal ini, kondisi di atas dikenal dengan istilah akuntabilitas yang sering digunakan di media maupun di jurnal akuntansi profesional dan akademik. Istilah ini biasanya digunakan untuk menggambarkan tanggung jawab yang dimiliki oleh mereka yang mengelola atau memiliki kontrol atas sumber daya kepada orang lain.

Ketika peneliti bertanya apakah ada akses khusus masyarakat terhadap informasi, adakah model khusus yang dapat ditiru oleh daerah lain, yang khusus dipakai misalnya untuk mengumumkan kepada masyarakat, inilah aktivitas/kegiatan yang sudah dikerjakan oleh pemda, apa ada forumnya atau ada mekanismenya? Informan (pemerintah daerah) menjawab:

Kalau kita, khusus pengelolaan keuangan daerah belum ada sampai ke sana, tapi terkait dengan pelaporan-pelaporan aksesnya itu lewat internet saja. Tapi misalnya kalau dibentuk forum di kecamatan, ... , terkait dengan program kegiatan kita belum, tetapi kalau kita di dinas pengelolaan keuangan daerah ini, hampir setiap minggu kita ke kecamatan, terkait dengan pengelolaan PBB. Dari pengelolaan PBB itu, ... misalnya kalau saya turun ke kecamatan melakukan evaluasi, saya combine dengan programprogram yang bersentuhan di kecamatan. Karena PBB itu merupakan salah satu sumber dana kan, jadi informasinya, informasi seperti itu.

Hal ini berbeda dengan penerapan negara-negara Barat, yang berpendapat bahwa struktur akuntabilitas yang efektif bergantung pada penyediaan informasi oleh "accountor" (agen) pada "accountee" (prinsipal). Pemberian informasi ini memberdayakan accountee dalam proses yang dapat membantu accountor "untuk mengekspos, meningkatkan dan mengembangkan hubungan sosial" (Burritt dan Welch, 1997). Pemberian tanggung jawab tidak cukup untuk membangun suatu hubungan akuntabilitas, harus terdapat juga suatu proses di mana accountor bertanggung jawab atas tindakan yang diambil dan konsekuensi yang menyertainya. Oleh karena itu, mekanisme penegakan sangat penting dalam akuntabilitas, di mana mekanisme ini terkait dengan kekuatan yang dimiliki oleh accountee.

Namun demikian berdasarkan hasil pengamatan dari perspektif pemerintah daerah, ternyata akuntabilitas keuanganlah yang paling utama dan bagi mereka tidak perlu lagi membuat model akuntabiltas lain apabila kewajiban akuntabilitas dasar telah terpenuhi. Dalam hal ini tampak bahwa terjadi perbedaan perspektif pemerintah daerah Kabupaten Gowa dengan penerapan pada negara-negara Barat (seperti New Zealand, UK, Australia) yang lebih menekankan pada akuntabilitas kebijakan. Hubungan akuntabilitas yang dibangun cenderung kepada tanggung jawab dan konsekuen si yang mungkin terjadi atas kebijakan yang diputuskan sebagaimana tampak pada gambar 2 di atas.

\section{"Sumbatan Informasi": Akuntabilitas Perspektif Masyarakat}

Pada uraian di atas, tampak bahwa terdapat sejumlah mekanisme akuntabilitas pemerintah daerah baik untuk anggota dewan maupun publik sebagaimana yang telah dilakukan di Kabupaten Gowa, namun dari perspektif masyarakat mekanisme tersebut belumlah cukup. Seperti yang diduga oleh Thynne dan Goldring dalam Burritt dan 
Welch (1997: 534) bahwa, masyarakat umum nya, cenderung membutuhkan terpenuhinya "hak untuk tahu" atas keputusan yang dibuat oleh organisasi sektor publik (dalam hal ini pemerintah daerah), termasuk terjaminnya kebutuhan "ingin tahu" masyarakat terkait apakah kekuasaan birokrat dan politisi disalahgunakan atau tidak.

Proses interaksi sehari-hari, sebagai bagian dari hubungan sosial yang berlangsung, merupakan "sistem akuntabilitas" yang terlihat, teramati, dan tercatat, istilah ini digunakan oleh Vosselman (2012) untuk merujuk pada sistem sebagaimana akuntabilitas diwujudkan dalam praktek. Dalam hal ini, membuat kumpulan asumsi ini menjadi eksplisit dapat membantu memahami akuntansi dalam praktek. Menurut informan (masyarakat):

Secara umum kan, dia (akuntabilitas) terstruktur, terhubung sampai ke camat, lurah, desa, dusun. Kalau informasi umum seperti itu pasti nyampai, dia terstruktur, tapi kan ada hal-hal lain (informasi lain) yang mungkin sangat perlu diperbaiki di sistem, ... jadi, ya ... masyarakat tidak punya kewenangan di situ karena sudah ada dari atas toh. Yang saya maksudkan ini dari bawah, coba dari bawah, kita balik ki, makanya biasa saya bilang itu coba kita balik, desa menjadi kota, menjadi kabupaten. (tanda kurung sebagai penegasan dan penjelasan).

Berdasarkan ungkapan di atas dapat disimpulkan bahwa selain akuntabilitas dasar (yaitu laporan keuangan), ternyata masyarakat juga membutuhkan akuntabilitas lain. Akuntabilitas yang diinginkan adalah akuntabilitas yang dapat memenuhi "right to know" dan "need to know" masyarakat. Oleh karena itu, informasi yang dicantumkan dalam akuntabilitas perlu digali dari masyarakat sebagaimana ungkapan informan bahwa "desa menjadi kota atau kabupaten". Hal ini berarti bahwa seluruh informasi akuntabilitas dapat memenuhi kebutuhan masyarakat bawah (grass root) atas informasi.
Berkaitan dengan hal tersebut di atas, studi ini menemukan bahwa informasi dan akuntabilitas, yang dilakukan oleh Pemda Gowa, tersumbat dengan sistem yang ada. Artinya, sistem tersebut menyumbat informasi yang seharusnya diketahui oleh masyarakat. Dalam hal ini saya tidak bermaksud bahwa tidak ada akuntabilitas, akan tetapi sistem jalur (channel) yang dipilih oleh Pemda Gowa belum berhasil menjangkau hak dan kebutuhan masyarakat untuk tahu (right to know and need to know).

Sejalan dengan hal ini, Parker dan Gould (1999) berargumen bahwa terdapat sifat melekat yang menyiratkan baik kendala maupun keadilan dalam akuntabilitas. Meskipun tidak dapat dihindari bahwa decision usefulness melibatkan penilaian tentang keadilan secara implisit (tidak harus transparan), namun akuntabilitas memungkinkan pertimbangan keadilan dibuat secara eksplisit yang memberi peluang masuknya kognisi moral dalam pengembangan dan pemahaman tentang sistem akuntabilitas.

Situasi di atas mencerminkan bahwa nilai-nilai etis dalam persamaan akuntabilitas perlu dipertimbangkan. Sebagaimana Lehman (1996 dalam Parker dan Gould, 1999) berpendapat bahwa akuntabilitas perlu menggabungkan baik dimensi strategis maupun etika yang mengakui adanya saling ketergantungan antara manusia dari generasi sekarang dengan generasi masa depan. Oleh karenanya, akuntansi berperan dalam menyediakan informasi kualitatif, dan perhatian lebih mengarah kepada pengungkapan sebagai bagian dari proses akuntabilitas. Pertimbangan tersebut memiliki relevansi tertentu pada lingkungan sektor publik.

\section{[Re] Konstruksi Akuntabilitas: Reaksi Dari Persepsi Masyarakat}

Akuntabilitas menurut pandangan Sinclair (1995), dapat ditingkatkan dengan memahami bagaimana manajer memaknai dan menggambarkan seseorang yang akuntabel. Dia menjelaskan bahwa akuntabilitas dapat dipahami sebagai sesuatu yang dirasakan seseorang, sesuatu yang telah 
diberikan oleh seseorang, baik sebagai kewajiban atau bagian dari kontrak kerja atau sebagai suatu timbal balik atas pemberian otoritas. Selain itu, dia juga menunjukkan bahwa akuntabilitas dipandang berbeda oleh berbagai pelaku. Sebagai contoh, auditor memandang akuntabilitas sebagai urusan keuangan, sementara ilmuwan politik melihatnya dari perspektif politik, dan komunitas hukum mendekatinya dari sudut pandang konstitusional. Perspektif dari administrator dan pimpinan organisasi akan mempengaruhi bagaimana sebuah lembaga menunjukkan akuntabilitasnya.

Selanjutnya secara kritis menurut konteks ilmu sosial, akuntabilitas dapat berarti mempertanyakan bagaimana pengetahuan masyarakat dapat ditingkatkan sesuai dengan fakta dan pengetahuan yang telah di verifikasi. Pengetahuan adalah suatu proses dinamis dan tidak bersifat statis. Pengetahuan bukan suatu wadah di mana setiap informasi dimasukkan ke dalamnya, dengan harapan informasi tersebut tergabung dan memberikan penjelasannya sendiri kepada dunia. Bagi penganut metodologi kritis, pengetahuan adalah proses menuju pemahaman tentang dunia dan pengetahuan yang menjadi struktur persepsi kita tentang dunia

Namun, beberapa peneliti menunjukkan bahwa pendekatan kritis dalam ilmu sosial terkadang membawa kita lebih jauh daripada yang diharapkan. Dengan berpikir radikal secara kritis atas masyarakat, peneliti mengambil sebuah lompatan untuk menjadi normatif dan menghakimi. Beberapa penulis seperti Webster (dikutip dalam Nnenna, 2012) misalnya, telah memperkenalkan beberapa definisi alternatif dari istilah kritis dalam kata ilmu sosial 'kritis'. Sebuah pemaknaan yang lemah apabila seorang peneliti hanyalah kritis dalam hal perdebatan, bukan atas tatanan sosial yang ada.

Ketika manusia terlibat dalam kegiatan perusahaan, ada satu di antara mereka yang mencoba untuk "menjelaskan" apa dan mengapa sebuah masalah terjadi. Ketika seseorang bermimpi, ia telah menjelaskan, dan ketika seseorang bertindak, ia memiliki alasan mengapa. Apabila ditinjau lebih jauh maka akuntabilitas merupakan salah satu konsep yang paling sering disebut dalam literatur akuntansi, dan merupakan salah satu konsep yang paling ambigu dalam pendefinisiannya. Banyak pemaknaan berbeda yang telah dikaitkan dengan istilah tersebut, dan sering meluas ke ranah tradisional yang merupakan bagian dari konsep lain, seperti tanggung jawab, etika, standar profesional atau pengendalian. Gagasan akuntabilitas bahkan telah digunakan untuk membangkitkan gambaran keandalan, kesetiaan dan keadilan, atau sebagai sinonim untuk pemerintahan yang baik (Mulgan, 2000; Van Thiel, 2000; Bovens, 2007).

Namun istilah ini memiliki epistemologi yang relatif sederhana. Mempertanggungjawabkan sesuatu berarti mengutip alasan yang menjelaskan perilaku tertentu (Burritt dan Welch, 1997). Konsep ini bersifat adaptatif, karena memiliki berbagai definisi berbeda. Menurut Sinclair (1995), kemungkinan besar bukan karena interpretasi yang berbeda dari istilah ini, tetapi karena variabilitas tujuan yang ditugaskan kepada accountors di mana mereka perlu mempertanggungjawabkan perilaku dan tindakan yang telah dilakukan. Selain itu, karena variabilitas prioritas kognitif dan kontrol rakyat (accountees) (Van Thiel, 2000).

Dalam pandangan saya, keadaan ini menjelaskan perbedaan utama yang biasanya dikaitkan dengan konsep akuntabilitas di sektor swasta dan sektor publik. Sebenarnya, dalam kedua kasus tersebut, maknanya berarti bertanggung jawab atas sesuatu. Akan tetapi, perbedaan mendalam yang mungkin ada adalah tujuan yang ditugaskan untuk accountors, dan kebutuhan kognitif serta kontrol yang berbeda dapat menimbulkan perubahan dalam bentuk dan isi instrumen pelaporan yang diperlukan. Perubahan tersebut mengarahkan seseorang untuk mendefinisikan akuntabilitas secara berbeda. 


\section{SIMPULAN DAN SARAN}

Penyediaan informasi, konsultasi kepada stakeholder merupakan komponen penting dalam akuntabilitas. Konsultasi tidak hanya meningkatkan hubungan organisasi dengan para pemangku kepentingan, tetapi juga memberikan kontribusi yang lebih bermakna pada pertanggungjawaban publik. Dalam hal ini, penting untuk memfasilitasi masukan dari stakeholder dan preferensi accountee dapat mendorong isi laporan akuntabilitas. Studi ini menemukan bahwa sudut pandang semua pihak yang berkepentingan harus dipertimbangkan dalam pemilihan langkah dan target kunci, dan diperlukan adanya pendekatan yang lebih partisipatif atas pengukuran dan evaluasi kinerja.

Berdasarkan pandangan beberapa informan maka akuntabilitas pemerintah Kabupaten Gowa saat ini dapat dimaknai sebagai sebuah metode yang menempatkan terlalu banyak penekanan pada aspek keuangan dan ekonomi. Pemerintah daerah lebih menyukai model pengukuran dan indikator sintetis (pendapatan merupakan yang pertama dan utama), dan tidak memungkinkan representasi eksplisit berkaitan dengan sejauh mana entitas publik telah mencapai tujuan yang telah dimandatkan secara spesifik kepada pemerintah. Selain itu, pemerintah daerah menempatkan posisi konsep akuntabilitas di bawah akuntansi, mereka (pemerintah daerah) memberikan prioritas yang lebih tinggi pada efisiensi dan "value for money" daripada efektivitas dan kejujuran. Hal ini terlihat dari analisis hasil wawancara dikatakan bahwa apabila akuntabilitas dasar telah terpenuhi maka hal lain dari akuntabilitas diabaikan.

Di sisi lain, masyarakat berharap bahwa akuntabilitas dapat meningkatkan pengungkapan informasi non-akuntansi dan nonkeuangan. Dalam hal ini, masyarakat harus dilibatkan ketika memformulasikan bentuk akuntabilitas sebab mereka sebagai elemen pemangku kepentingan merupakan kelompok atau individu yang memengaruhi atau dipengaruhi oleh pencapaian tujuan organisasi yang terwujud dalam akuntabilitas.

Studi ini juga menemukan bahwa pemerintah Kabupaten Gowa belum melakukan upaya sukarela untuk menyesuaikan model pengelolaan dan pelaporan mereka sesuai dengan kebutuhan khas akuntabilitas sektor publik. Penyesuaian semacam ini seharusnya dimulai dari pendefinisian dengan jelas tujuan yang ditugaskan pada pemerintah daerah, sehingga dapat ditemukan indikator untuk mengukur sejauh mana tujuan telah tercapai. Artinya, indikator ini dapat digunakan bersamaan dengan indikator ekonomi dan keuangan yang lebih tradisional.

\section{DAFTAR PUSTAKA}

Aveh, F. K. 2013. A critique of Sayers: statement in the context of social research. Research on Humanities and Social Sciences 3(13). ISSN 2222-1719 (Paper), ISSN 2222-2863 (Online). www.iiste.org. Diakses bulan Juni tahun 2013.

Borgonovi, E., dan E. Anessi-Pessina Eugenio. 1998. User needs and financial reporting requirements for Italian Local Authorities. The paper presented at Naples International Accounting Conference. Italia.

Bovens, M. 2007. Public Accountability. in The Oxford Handbook of Public Management. 2007. edited by E. Ferlie, L. E. Lynn, dan C. Pollitt. New York: Oxford University Press. USA.

Burritt, R. L. dan S. Welch. 1997. Accountability for environmental performance of the Australian Commonwealth public sector. Accounting Auditing and Accountability Journal 10(4): 532-561.

Caccia, L. dan I. Steccolini. 2006. Accounting and Organizational Change in Italian Local Governments: What's Beyond Managerial Fashion?. Critical Perspective on Accounting 17(2/3): 154-174.

Campos, E. 2007. Enhancing Public Sector Accountability: The Role of Civil Society. MeTA Meeting The Royal Society. April 18. London United Kingdom. 
Chan, J. 2003. Government accounting: an assessment of theory, purposes and standards. Public Money and Management 23(1): 13-20.

Damayanti, R.A., Syarifuddin, Darmawati, dan A. Indrijawati. 2012. Reformasi Akuntabilitas dan Sistem Informasi Akuntansi Kajian Empiris di Pemerintah Kabupaten Gowa Sulawesi Selatan. Penelitian tidak dipublikasi. Makassar.

Dillard, J. F. 1984. Cognitive science and decision making research in accounting. Accounting, Organization and Society 9(34): 343-354.

Ellwood S. dan A. Wynne. 2003. An accrual world? The transition to accrual accounting in context, 9th Comparative International Government Accounting Research (CIGAR) Conference. Bodø. Norway.

Ezzamel, M., K. Robson, P. Stapleton, dan C. McLean. 2007. Discourse and institutional change: 'Giving accounts' and accountability. Management Accounting Research 18: 150-171.

Gårseth-Nesbakk , L. dan G. Paulsson. 2012. What do we really know about the use of accounting information in the public sector? Working Paper.

Giddens, A. 1984. The constitution of society: an outline of the theory of structuration. Polity Press. Cambridge.

Goddard, A. dan J. Powell. 1994. Accountability and Accounting Using Naturalistic Methodology to Enhance Organizational Control: A Case Study. Accounting Auditing and Accountability Journal 7(2): 50-69.

Guthrie, J. 1998. Application of accrual accounting in the Australian Public Sector: Rhetoric or Reality?. Financial Accountability and Management 14 (1): 319.

Hood, C. 1995. The new public management in the 1980s: Variations on a theme, Accounting Organisations and Society 20(2-3): 93-109.

Hoopwood, A. dan C. Tomkins. 1984. The Role of Information in Public Accounta- bility: Issues in Public Sector Accounting, edited by, Philip Allan Publishers Limited. Great Britain.

Hoque, Z., dan C. Adams. 2011. The rise and use of balanced score card measures in Australian government departments. Financial Accountability and Management 27(3): 308-334.

Jansen, P. 2008. New Public Management: Perspectives on performance and the use of performance information. Financial Accountability and Management 24(2): 169-191.

Jones, S. dan N. Puglisi. 1997. The relevance of AAS 29 to the Australian public sector: A cause for doubt? Abacus 33: 118.

Kida, T. dan J.F. Smith. 1995. The Encoding and Retrieval of Numerical Data for Decision Making in Accounting Contexts: Model Development. Accounting, Organizations and Society 20(7/8): 585610.

Lawton, A., D. McKevitt, dan M. Millar. 2000. Coping with Ambiguity: Reconciling External Legitimacy and Organizational Implementation in Performance Measurement. Public Money and Management 6(2): 93-114.

Lehman, G. 1996. Environmental accounting: pollution permits or selling the environment. Critical perspectives on accounting 7(5): 667-676.

Libby, R. dan R. Bloomfield. 2002. Experimental research in financial accounting. Accounting, Organizations and Society 27: 775-810.

Manao, H. dan D. Martani. 2009. Accrual Accounting: Would The Economy Benefit If Governments Adopt It? - Lesson From Indonesia. The $16^{\text {th }}$ ASEAN Federation of Accountants (AFA) Conference. December 8-9. Brunei Darussalam.

Mellemvik, F., N. Monsen, dan O. Olson. 1988. Functions of accounting-A discussion. Scandinavian Journal of Management 4(3/4): 101-119. 
Mulgan, R. 2000. Accountability: An everexpanding concept?. Public Administration 78(3): 555-73.

Neu, D. 2000. Accounting and accountability relations: colonization, genocide and Canada's first nations. Accounting Auditing \& Accountability Journal 13 (3): 268-288.

Nnenna, O.M. 2012. The Use Accounting Information as an Aid to Management in Decision Making, British Journal of Science 5(1): 52-62.

Parker, L. dan G. Gould. 1999. Changing public sector accountability: critiquing new directions. Accounting Forum 23(2): June.

Peraturan Pemerintah No. 24 tahun 2005 tentang Standar Akuntansi Pemerintahan.

Peraturan Pemerintah No. 3 tahun 2007 tentang Laporan Pemerintah Daerah.

Peraturan Pemerintah No. 71 tahun 2010 tentang Standar Akuntansi Pemerintahan.

Peters, J. M. 1993. Decision making, cognitive science and accounting: An overview of the intersection. Accounting, Organizations and Society 18(5): 383-405.

Pettersen, I. J. 2001. Implementing Management Accounting Reforms in the Public Sector: The Difficult Journey from Intentions to Effects. European Accounting Review 10(3): 561-81.

Pilcher, R. A. 2004. Political Influence On Accounting Policy Choice -Local Government Reform In Australia. Accepted for Presentation at the Fourth Asia Pacific Interdisciplinary Research in Accounting Conference 4 to 6 July. Singapore.

Roberts, J. 1991. The possibilities of accountability. Accounting organizations and society $16(4)$ : $355-368$.
Sinclair, A. 1995. The chameleon of accountability: forms and discourses. Accounting Organizations and Society 20(2/3): 219-237.

Soudani, S.N. 2012. The Usefulness of an Accounting Information System for Effective Organizational Performance. International Journal of Economics and Finance 4(5): May.

Stewart, J.D. 1984. The role of information in public accountability. in A. Hopwood dan C. Tomkins. (eds.). Issues in Public Sector Accounting 13-34. Philip Allan Publishers. Oxford.

Ter Bogt, H.J. 2004. Politicians in search of performance information? -Survey research on Dutch aldermen's use of performance information. Financial Accountability and Management 20(3): 221-252.

Undang-Undang No 17 tahun 2003 tentang Keuangan Negara.

Van Thiel, S. 2000. Quangocratization: Trends, Causes and Consequences. in NN. 2012. Accountability of Italian state owned enterprises and private sector type financial reporting: an Imperfect Match, Electronic copy available at: http://ssrn.com/abstract=2153899. Diakses Juni 2013.

Vosselman, E. 2012. Accounting, accountability and virtue ethics in public organizations: from market bureaucracies to moral communities. Nijmegen Center for Economics (NiCE). August. Working Paper: 12-105.

Wahid, S. 1992. Metafora Bahasa Makassar. Disertasi. Program Pascasarjana Universitas Hasanuddin. Makassar. 